University of Nebraska - Lincoln

DigitalCommons@University of Nebraska - Lincoln

\title{
Interleukin-6 and Tumor Necrosis Factor-Alpha Values in Elk Neonates
}

\author{
Shannon M. Barber-Meyer \\ University of Minnesota, Saint Paul, sbarber-meyer@usgs.gov \\ Craig R. Johnson \\ University of Minnesota, Saint Paul \\ Michael P. Murtaugh \\ University of Minnesota, Saint Paul, murta001@umn.edu \\ L. David Mech \\ USGS Northern Prairie Wildlife Research Center, david_mech@usgs.gov \\ P. J. White \\ Yellowstone National Park
}

Follow this and additional works at: https://digitalcommons.unl.edu/usgsnpwrc

Part of the Other International and Area Studies Commons

\footnotetext{
Barber-Meyer, Shannon M.; Johnson, Craig R.; Murtaugh, Michael P.; Mech, L. David; and White, P. J., "Interleukin-6 and Tumor Necrosis Factor-Alpha Values in Elk Neonates" (2007). USGS Northern Prairie Wildlife Research Center. 106.

https://digitalcommons.unl.edu/usgsnpwrc/106
}

This Article is brought to you for free and open access by the US Geological Survey at DigitalCommons@University of Nebraska - Lincoln. It has been accepted for inclusion in USGS Northern Prairie Wildlife Research Center by an authorized administrator of DigitalCommons@University of Nebraska - Lincoln. 


\title{
INTERLEUKIN-6 AND TUMOR NECROSIS FACTOR-ALPHA VALUES IN ELK NEONATES
}

\author{
Shannon M. Barber-Meyer,* Craig R. Johnson, Michael P. Murtaugh, L. David Mech, and P. J. White \\ Department of Fisheries, Wildlife, and Conservation Biology, 200 Hodson Hall, 1980 Folwell Avenue, \\ University of Minnesota, Saint Paul, MN 55108, USA (SMB-M) \\ Department of Veterinary \& Biomedical Sciences, 1971 Commonwealth Avenue, University of Minnesota, \\ Saint Paul, MN 55108, USA (CRJ, MPM) \\ Northern Prairie Wildlife Research Center, United States Geological Survey, Jamestown, ND 58401, USA (LDM) \\ National Park Service, P.O. Box 168, Yellowstone National Park, WY 82190, USA (PJW)
}

\begin{abstract}
Serological indicators of general condition would be helpful for monitoring or assessing ungulate wildlife. Toward that end, we report the 1st reference values for 2 cytokines, interleukin-6 (IL-6) and tumor necrosis factor-alpha (TNF- $\alpha$ ), in neonatal elk (Cervus elaphus). We obtained blood samples from 140 calves $\leq 6$ days old in Yellowstone National Park during summer 2003-2005. IL-6 values ranged from 0 to $1.21 \mathrm{pg} / \mathrm{ml}$ with a median of $0.03 \mathrm{pg} / \mathrm{ml}$. TNF- $\alpha$ values ranged from 0 to $225.43 \mathrm{pg} / \mathrm{ml}$ with a median of $1.85 \mathrm{pg} / \mathrm{ml}$. IL-6 and TNF- $\alpha$ concentrations were not significant predictors of elk calf survival through 21 days. Development of ungulate-based IL- 6 and TNF- $\alpha$ assays that provide greater sensitivity than cross-reacting human-based assays could be helpful in monitoring ungulate condition and health status comparisons among herds. Such information could provide indirect assessments of range quality or environmental influences among herds.
\end{abstract}

Key words: Cervus elaphus, cytokine, elk, immunocompetence, interleukin-6, survival, tumor necrosis factor-alpha, Yellowstone

Biomarkers measurable in blood or serum and that accurately reflect general condition of ungulates may provide insights into the biology and ecology of native populations, and facilitate habitat and population management. Hematologic and metabolic measures have been evaluated with variable results (Franzmann and LeResche 1978; Hamlin and Ross 2002; Kie et al. 1983; Kirkpatrick et al. 1975; LeResche et al. 1974; Seal and Hoskinson 1978; Seal et al. 1978a, 1978b; Weber et al. 1984). More recently, cytokines such as interleukin-6 (IL-6) and tumor necrosis factor-alpha $(\mathrm{TNF}-\alpha)$ have been evaluated as predictors of neonatal condition and survival in white-tailed deer (Odocoileus virginianus-Carstensen Powell 2004; M. Carstensen Powell et al., in litt.; Ditchkoff et al. 2001; see also Call et al. 2000). Cytokines are proteins that function as chemical messengers secreted by T-cells in immune responses and have been most thoroughly studied in mouse (Mus) and human models (Remick and Friedland 1997).

Interleukin-6 is a proinflammatory cytokine involved in cytotoxic T-cell differentiation, B-cell immunoglobulin release,

*Correspondent: shannonbarbermeyer@gmail.com

(C) 2007 American Society of Mammalogists www.mammalogy.org

This article is a U.S. government work, and is not subject to copyright in the United States. and inflammatory responses (Spaulding et al. 1997; Tizard 1992). Elevated concentrations of IL-6 have been associated with human disorders including heart disease, osteoporosis, arthritis, type 2 diabetes, cancer, periodontal disease, increased reactions to viral infections, septicemia, and mortality in elderly humans (Cannon 1995; Damas et al. 1992; Ferrucci et al. 1999; Harris et al. 1999; Pradhan et al. 2001). Elevated IL-6 also has been reported in stressed animals such as oiled North American river otters (Lontra canadensis-Duffy et al. 1994a, 1994b). However, laboratory mice fed a 50\% calorie-reduced diet had decreased concentrations of IL-6 (Spaulding et al. 1997). Ditchkoff et al. (2001) noted that IL-6 concentrations may be confounded by low birth weights, because the ability to initiate an inflammatory response is compromised while experiencing protein stress (see also Sams 1994). Low birth weights have also been associated with low survival (Carstensen Powell 2004; M. Carstensen Powell et al., in litt.; Sams et al. 1996; Ditchkoff et al. 2001).

Tumor necrosis factor-alpha is another cytokine that functions as a major mediator in host immune responses including the production of IL-6 (Beutler and Cerami 1989), lysis of virally infected cells, and antitumor activity (Spaulding et al. 1997). Elevated TNF- $\alpha$ likely indicates that the animal is stressed and undergoing an immune response (Ditchkoff et al. 2001). Elevated TNF- $\alpha$ concentrations have been associated 


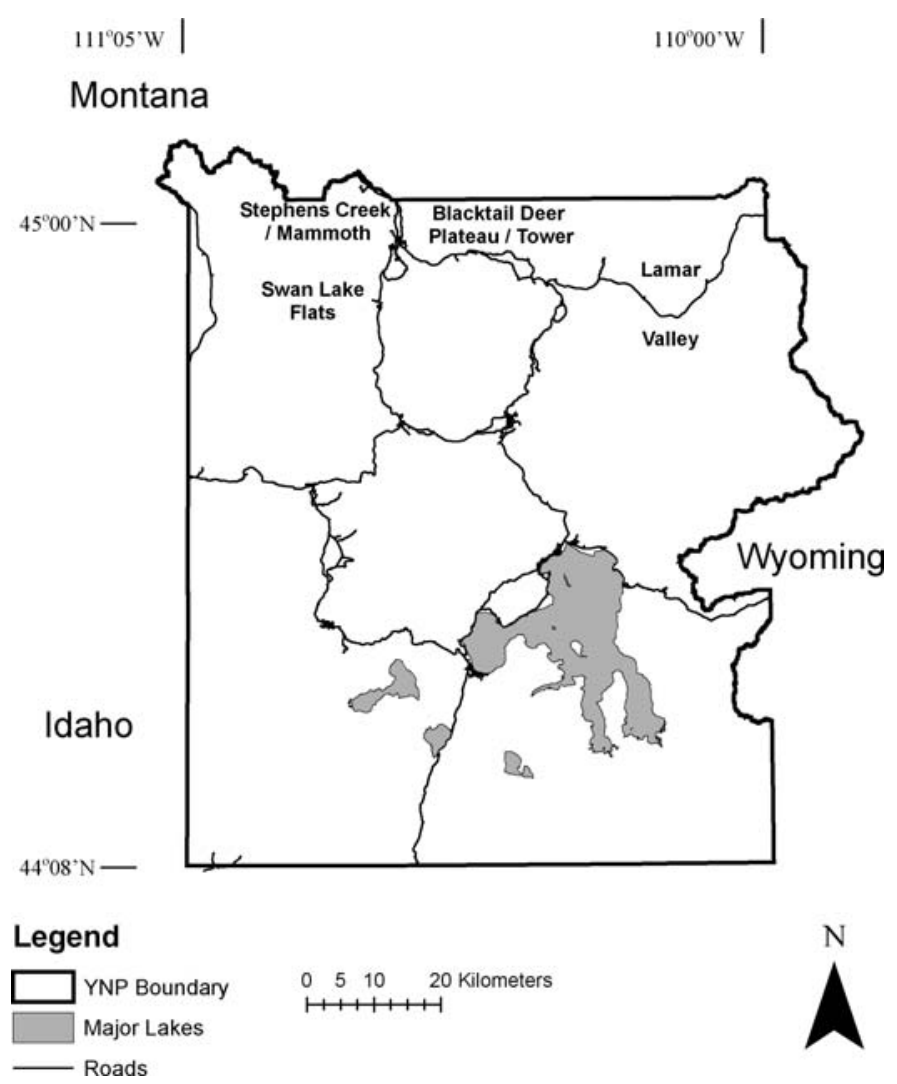

Fig. 1.-Yellowstone National Park. Major elk calving areas on the northern range include Stephens Creek/Mammoth, Swan Lake Flats, Blacktail Deer Plateau/Tower, and Lamar Valley.

with body-wasting and with increased mortality in neonate white-tailed deer (M. Carstensen Powell et al., in litt.; Ditchkoff et al. 2001).

The goal of the present study was to determine if IL-6 or TNF- $\alpha$ levels in serum were associated with survival of freeranging neonate elk (Cervus elaphus). In addition, reference values for elk were established for the 1st time. Characterization of IL- 6 and TNF- $\alpha$ concentrations in wild elk may contribute to the understanding of disease processes and improve assessments of health status, general condition, and factors influencing survival in ungulates (Call et al. 2000; Lochmiller et al. 1994).

\section{Materials ANd Methods}

Our study area consisted of the calving, summer, and winter ranges of the northern Yellowstone elk herd of Yellowstone National Park (Fig. 1; Cook et al. 2004; Houston 1982). Yellowstone National Park encompasses 8,991 $\mathrm{km}^{2}$ of Wyoming, Montana, and Idaho in the western United States ( $44^{\circ} \mathrm{N}$ latitude and $110^{\circ} \mathrm{W}$ longitude). Elevations along the northern range of the park extend from 1,500 to $>3,300 \mathrm{~m}$ (Houston 1982) and generally are higher in the northeastern portions and lower in the northwestern portions of Yellowstone National Park. Annual precipitation varies from $25 \mathrm{~cm}$ (30-35\% as snow) at low elevations to $180 \mathrm{~cm}(70 \%$ as snow) at high elevations (Farnes et al. 1999).
During our study, the northern Yellowstone elk herd consisted of approximately 12,000 elk that wintered and calved in the northern portion of the park and adjacent areas of Montana. This northern range is characterized by lower elevations $(1,550-$ $2,500 \mathrm{~m})$ and a milder climate $(31.7 \mathrm{~cm}$ annual precipitation; $1.8^{\circ} \mathrm{C}$ mean temperature) than the rest of Yellowstone National Park (Houston 1982). Vegetation is composed primarily of big sagebrush (Artemisia tridentata), Idaho fescue (Festuca idahoensis), Douglas-fir (Pseudotsuga menziesii), and quaking aspen (Populus tremuloides-Despain 1990).

Ungulates sympatric with northern Yellowstone elk on their winter range included approximately 700-1,000 American bison (Bison bison), 2,000-2,500 mule deer (Odocoileus hemionus), 175-250 bighorn sheep (Ovis canadensis), 200250 pronghorn (Antilocapra americana), <200 moose (Alces alces), $<100$ mountain goats (Oreamnos americanus), and a few white-tailed deer (White and Garrott 2005). Major sympatric predators included an unknown number of American black bears (Ursus americanus; K. Gunther, National Park Service, Yellowstone National Park, in litt.), and approximately 70-92 grizzly bears ( $U$. arctos-Haroldson and Frey 2005; K. Gunther, National Park Service, Yellowstone National Park, in litt.), 20 cougars (Puma concolor-Ruth 2004), 225 coyotes (Canis latrans-Crabtree and Sheldon 1999), and 50-100 wolves (C. lupus-Smith 2005).

To the extent feasible, we replicated the methodology and experimental design used by Singer et al. (1997) to capture and monitor elk neonates during 1987-1990. We located neonate elk calves $\leq 6$ days old, as indicated by their wet coats, wobbly stances, and attached umbilical cords (Johnson 1951), from both air and ground (see Barber et al. 2005). We attempted ground captures on calves observed opportunistically during 16 May-20 June 2003-2005. We conducted aerial searches using a Bell Jet Ranger helicopter during 2-3 days in early (19 May-25 May), middle (31 May-4 June), and late (6-10 June) portions of the calving season (i.e., 6-9 days per year). The pilot flew transects over 4 traditional calving areas, encompassing (from west to east across the northern portions of Yellowstone National Park) the Stephens Creek/Mammoth (Sepulcher Mountain foothills), Swan Lake Flats, Blacktail Deer Plateau/Tower, and Lamar Valley areas (Fig. 1). When we spotted a calf, the pilot landed in the vicinity and we manually captured the calf. We captured and handled all elk in compliance with requirements of the Institutional Animal Care and Use Committee for the University of Minnesota and with the guidelines recommended by the American Society of Mammalogists (Animal Care and Use Committee 1998). We completed procedures in approximately $8 \mathrm{~min}$.

We determined sex and age (Johnson 1951), and weighed each calf to the nearest $0.23 \mathrm{~kg}(0.5 \mathrm{lb})$ using a handheld spring scale and ground cloth that enclosed and supported the animal's entire body. We measured each calf's body contour length (from nose to base of tail), hair moisture, dentition, hoof and dewclaw wear, hind-foot length, eye to nose-tip length, navel healing, and numbers of ticks in each ear (Haugen and Speake 1958; Johnson 1951). We drew approximately $20-25 \mathrm{ml}$ of blood from elk calves by puncture of the jugular vein. We placed blood in sterile, 
10-ml, serum-separating tubes and centrifuged the blood within $4 \mathrm{~h}$ of collection. We stored serum in cryovials $(2-5 \mathrm{ml})$ in a cooler chilled with ice packs until transport to a freezer $\left(-60^{\circ} \mathrm{C}\right.$; within 1-8 h). We shipped serum samples overnight on ice packs to the University of Minnesota Department of Veterinary and Biomedical Sciences (St. Paul, Minnesota) for IL-6 and TNF- $\alpha$ assaying at the end of each summer capture season. We performed cytokine tests using a human-based, enzyme-linked immunosorbent assay (ELISA) as human-cytokine equivalents (human IL-6 ultrasensitive ELISA kit, catalog no. KHC0064; BioSource International, Inc., Camarillo, California; and TNF- $\alpha$ kit, catalog no. IM1121; Beckman Coulter, Miami, Florida). The manufacturer-reported sensitivity was $0.094 \mathrm{pg} / \mathrm{ml}$ for the IL-6 kit and $5 \mathrm{pg} / \mathrm{ml}$ for the TNF- $\alpha$ kit. Both negative responses (zeros) and nonzero values obtained below the detection levels were included in these analyses because porcine-validated ELISA tests indicate that the normal concentrations of cytokines are at or below these levels (M. Murtaugh et al., in litt.).

We fit each calf with an ear-tag transmitter (model 3430; Advanced Telemetry Systems, Inc., Isanti, Minnesota) weighing approximately $23 \mathrm{~g}$ and designed to emit a radiosignal each day for $12 \mathrm{~h}$ for approximately 1 year. Each transmitter changed pulse rate if it remained motionless for $>4 \mathrm{~h}$. This change in pulse rate (i.e., "mortality mode/signal") alerted us that the animal was likely dead and enabled us to examine the carcass soon after death (Adams et al. 1995; Garner et al. 1985; Larsen et al. 1989; O'Gara 1978). Thus, the transmitters allowed us to quickly and conveniently monitor daily survival without visually locating each animal.

During May through mid-July, when the risk of mortality to calves was relatively high, we monitored transmitter frequencies of ear-tagged calves via airplane (Montana Aircraft, Belgrade, Montana) each day at dawn to evaluate if each calf's radiotransmitter was on active or mortality mode. As calves became older and less prone to predation because they were able to escape predators by running (Altmann 1952; Geist 2002), we reduced aerial monitoring to 3 times per week during mid- to late July, twice per week during August-21 September, and bimonthly thereafter (except during September 2005-May 2006 when we monitored calf signals aerially approximately once per 10 days). The pilot obtained locations (i.e., universal transverse mercator coordinates) for all dead calves using a global positioning system unit and searched the vicinity of the carcass for predators to reduce the risk of ground crews surprising large predators nearby. Ground crews also monitored transmitter frequencies of ear-tagged calves 3 or 4 times per day until mid-July and less frequently (i.e., approximately 4 times per week) during mid-July to the following July, except during 2005 when ground tracking ended in late August 2005.

Ground crews investigated mortality sites and conducted necropsies of dead calves to evaluate causes of death based on evidence such as predator tracks, consumption patterns, canine puncture measurements, and scat measurements (O'Gara 1978; Wade and Bowns 1985). Crews also collected a long-bone midsection and metatarsus for calf-condition analyses and predator hair samples for species identification (Moore et al. 1974) by L. Waits and C. Anderson of the University of Idaho
(Laboratory for Ecological \& Conservation Genetics) and K. Pilgrim (1 sample) of the Carnivore Conservation Genetics Laboratory (United States Forest Service).

We coded fates of calves through the first 21 days of life as survivor, mortality, or censored. We evaluated mortality events following methods modified from those used by Garner et al. (1985) and Kunkel and Mech (1994). We concluded that a carcass was scavenged if we determined no evidence of subcutaneous hemorrhaging; no aspirated blood in mouth, nose, or trachea; and no signs of struggle including scuff or track evidence of chase and struggle, blood on the ground from pursuit, broken branches, or blood on trees. Possible censored fates included missing radio signals, inability to examine potential mortality cites, and possible transmitter pull-outs (only an intact transmitter was located and no remains of a calf carcass, evidence of an attack, or predator evidence were found).

We estimated calf birth masses from capture masses using sex-specific linear regression of estimated age of all calves $\geq 1$ day old versus capture mass (Smith et al. 1997). We assumed capture masses of calves $<1$ day old to be their birth masses. We used Mann-Whitney $U$-tests to evaluate whether IL-6 and TNF$\alpha$ concentrations varied between surviving and nonsurviving elk calves through 21 days from birth. We used logistic regression to evaluate the importance of IL- 6 and TNF- $\alpha$ in predicting survival through 21 days from birth in elk calves. Following Ditchkoff et al. (2001), we used stepwise forward model selection and permitted predictors to enter and remain in the model when the change in model deviance was significant at $\alpha$ $\leq 0.15$ (evaluated as a chi-square test using 1-cumulative probability of the deviance difference and degrees of freedom difference between models). For logistic regression, we transformed IL- 6 and TNF- $\alpha$ concentrations to base 10 logarithms to stabilize variance and remove curvature among residuals (Krebs 1999). Because both concentrations contained numerous zero values, we added 0.5 to each value before transforming to base 10 logarithms (Krebs 1999). We also considered the following predictors in the logistic regression model: capture age (days), birth date (days), absolute deviation from median birth date (days), estimated birth mass ( $\mathrm{kg}$ ), length (nose to tail, $\mathrm{cm}$ ), capture mass/length $\left(\mathrm{g} / \mathrm{dm}^{3}\right)$, capture area, capture year, and sex. We evaluated the final logistic regression model against the full model via a chi-square test using 1-cumulative probability (deviance difference and degrees of freedom difference between models). We used a conservative test for overdispersion in our data by dividing the deviance from the full model by the degrees of freedom to obtain a parameter $c$ (McCullagh and Nelder 1989), for which values of 1 indicated no dispersion, 2 moderate dispersion, and 3 extreme dispersion in the data. Overdispersion can result from lack of independence in the data. We performed Mann-Whitney $U$-tests using Statistica version 6 (StatSoft, Tulsa, Oklahoma) and all other statistical tests using Arc version 1.06 (Cook and Weisberg 1999).

\section{ReSUlts}

Concentrations of IL- 6 and TNF- $\alpha$ in elk neonates varied considerably, with many samples below the sensitivity of the 
TABLE 1.-Concentrations ( $\mathrm{pg} / \mathrm{ml}$ ) of interleukin-6 (IL-6) and tumor necrosis factor-alpha (TNF- $\alpha$ ) in serum samples collected from elk calves $\leq 6$ days old in Yellowstone National Park during 20032005.

\begin{tabular}{lll}
\hline & $\mathrm{IL}-6(\mathrm{pg} / \mathrm{ml})$ & $\mathrm{TNF}-\alpha(\mathrm{pg} / \mathrm{ml})$ \\
\hline$n$ & 138 & 140 \\
$\bar{X}(S E)$ & $0.07(0.01)$ & $9.93(2.16)$ \\
Median & 0.03 & 1.85 \\
Range & $0-1.21$ & $0-225.43$ \\
\hline
\end{tabular}

assay (Table 1). Both IL-6 and TNF- $\alpha$ distributions were positively skewed and contained a large proportion of zero values (IL-6, 37.0\% zeros [51/138]; TNF- $\alpha$, 31.4\% zeros [44/ 140]; Table 2).

Although mean concentrations of IL- 6 and TNF- $\alpha$ were higher and lower, respectively, in surviving elk calves than in nonsurvivors through 21 days from birth (Table 3), their rank sum differences were not significant (IL-6, $U=2,140, z=$ $0.560, P=0.58$; TNF- $\alpha, U=2,223, z=0.434, P=0.66)$. Also, logistic regression indicated that IL- 6 and TNF- $\alpha$ were not significant predictors of elk calf survival through 21 days from birth.

A comparison of IL- 6 and TNF- $\alpha$ median values and ranges for neonate elk and white-tailed deer indicated large variability within and between species (Table 2). IL-6 median values for elk neonates were lower than those for white-tailed deer neonates in Minnesota and Oklahoma (M. Carstensen Powell et al., in litt.; S. Ditchkoff et al., in litt.). TNF- $\alpha$ median values for elk calves were within the large range observed for white-tailed deer (M. Carstensen Powell et al., in litt.; S. Ditchkoff et al., in litt.). Our elk calf data included more zero responses for both IL- 6 and TNF- $\alpha$ and more responses below kit-specified detection concentrations for IL- 6 than in 2 white-tailed deer studies (M. Carstensen Powell et al., in litt.; S. Ditchkoff et al., in litt.; Table 2).

\section{Discussion}

We report the 1st reference values for IL- 6 and TNF- $\alpha$ in neonate elk using human-based ELISA (Table 1). IL-6 and TNF- $\alpha$ concentrations were not significantly different between surviving elk calves through 21 days from birth and nonsurvivors (Table 3), and neither was an important predictor of survival through 21 days from birth.

Ditchkoff et al. (2001) and M. Carstensen Powell et al. (in litt.), in studies of white-tailed deer, also found that IL-6 was not an important predictor of survival. However, in contrast to our TNF- $\alpha$ results, Ditchkoff et al. (2001) found TNF- $\alpha$ concentrations to be of limited importance as a predictor of survival through 21 days from birth $(P<0.10)$ and Carstensen Powell et al. (in press) found that TNF- $\alpha$ concentrations tended to vary by survival during weeks 2-4 from birth $(P=0.10)$. Although we found no evidence that either IL-6 or TNF- $\alpha$ concentrations were important predictors of elk calf survival, this may have been a function of the generally poorer sensitivity of the human-based assay kits when used with elk serum rather than white-tailed deer serum (Table 2).

The values of IL- 6 and TNF- $\alpha$ for elk calves in Yellowstone National Park were substantially different from those reported for white-tailed deer in Minnesota and Oklahoma (Table 2). The variability within the white-tailed deer data also was substantial within and among studies (Table 2). Several explanations exist for this variability, including different levels of cross-reactivity between species and different methods in determining immunoreactive cytokine concentrations (e.g., varying kits; see descriptions in Ditchkoff et al. [2001] and Carstensen Powell [2004]). Because elk neonates in our study and the white-tailed deer neonates in both Carstensen Powell et al. (2005) and Ditchkoff et al. (2001) were all physically restrained (i.e., not chemically immobilized), it is possible that the much higher IL- 6 and TNF- $\alpha$ concentrations reported by Ditchkoff et al. (2001) could have been a result of differences in cytokine assay kits. Although we used the same kits precisely to avoid comparison problems, the cytokine analyses of Ditchkoff et al. (2001) were completed approximately 10 years earlier. It is likely that modifications to improve assay performance over a period of 10 years make it difficult to directly compare results. Although these cytokines appear to be limited in their current utility, development of ungulate-based IL- 6 and TNF- $\alpha$ ELISA and additional research exploring the ranges of IL- 6 and TNF- $\alpha$ reference values in captive animals fed diets of varying quality would aid in interpreting values

TABLE 2.-Median concentrations in $\mathrm{pg} / \mathrm{ml}$ ( $n$, range) of interleukin-6 (IL-6) and tumor necrosis factor-alpha (TNF- $\alpha$ ) and percent of zero responses and total percent of concentrations below kit sensitivity including zeros in serum samples collected from neonate elk in Yellowstone National Park (YNP) during 2003-2005 compared to values for white-tailed deer fawns in Oklahoma (OK; S. Ditchkoff et al., in litt.) and Minnesota (MN; M. Carstensen Powell et al., in litt.).

\begin{tabular}{|c|c|c|c|}
\hline Cytokine (pg/ml) & YNP calf elk & OK deer fawns & MN deer fawns \\
\hline IL-6 median ( $n$, range) & $0.03(138,0-1.21)$ & $0.47(60,0-8.49)$ & $0.19(79,0-1.53)$ \\
\hline IL-6 \% zero responses & $37.0(51 / 138)$ & $16.7(10 / 60)$ & $3.80(3 / 79)$ \\
\hline IL-6 \% total below sensitivity & $79.0(109 / 138)$ & $25.0(15 / 60)^{\mathrm{a}}$ & $32.9(26 / 79)$ \\
\hline TNF- $\alpha$ median ( $n$, range) & $1.85(140,0-225.43)$ & $205.76(60,0-1,426.11)$ & $0.96(78,0-31.37)^{\mathrm{b}}$ \\
\hline TNF- $\alpha \%$ zero responses & $31.4(44 / 140)$ & $21.7(13 / 60)$ & $20.5(16 / 78)^{\mathrm{b}}$ \\
\hline TNF- $\alpha \%$ below sensitivity & $62.9(88 / 140)$ & $21.7(13 / 60)$ & $83.3(65 / 78)^{\mathrm{b}}$ \\
\hline
\end{tabular}

\footnotetext{
${ }^{a}$ The manufacture-reported sensitivity for the IL-6 kit used by Ditchkoff et al. (2001) was $0.104 \mathrm{pg} / \mathrm{ml}$.

${ }^{\mathrm{b}}$ One case with a TNF- $\alpha$ concentration of $554 \mathrm{pg} / \mathrm{ml}$ was censored in Carstensen Powell et al. (2005) and also was not included in this analysis.
} 
TABLE 3.-Cytokine values in elk calf survivors through 21 days and in nonsurvivors in Yellowstone National Park during 2003-2005.

\begin{tabular}{lcr}
\hline \multicolumn{1}{c}{ Cytokine $^{\mathrm{a}}$} & Survivors & \multicolumn{1}{c}{ Nonsurvivors } \\
\hline IL-6 $\bar{X}(S E, n)$ & $0.09(0.03,56)$ & $0.05(0.01,81)$ \\
TNF- $\alpha \bar{X}(S E, n)$ & $9.20(2.31,56)$ & $10.54(3.29,83)$ \\
\hline${ }^{a}$ IL-6 = interleukin-6; TNF- $\alpha=$ tumor necrosis factor-alpha. Values are in $\mathrm{pg} / \mathrm{ml}$.
\end{tabular}

${ }^{\mathrm{a}} \mathrm{IL}-6=$ interleukin-6; TNF- $\alpha=$ tumor necrosis factor-alpha. Values are in $\mathrm{pg} / \mathrm{ml}$.

obtained from wild populations, especially when considered along with other potential condition-indicator blood characteristics (DelGiudice et al. 1992).

\section{ACKNOWLEDGMENTS}

Special thanks to Dr. F. Singer for consultation and assistance during project design and implementation. We also thank E. Albers, T. Bedgood, B. Bering, T. Caddy, T. Clark, B. Colasuonno, C. Crowe, T. Davis, V. Green, C. Hanson, T. Lemke, K. Loveless, M. St. Martin, W. Neighbors, D. Ravenel, and J. Smith for assisting with fieldwork. Hawkins \& Powers (Greybull, Wyoming) and Central Helicopters (Bozeman, Montana) conducted helicopter flights. D. Krapf, W. Hafer, and M. Wagner served as helicopter managers. T. Lemke of Montana Fish, Wildlife and Parks assisted with aerial capture. D. Chapman and B. Walton of Montana Aircraft conducted monitoring flights. Funding for this study was provided by the National Park Service; the Biological Resources Discipline of the United States Geological Survey; the Yellowstone Park Foundation; Montana Fish, Wildlife and Parks; the Graduate School of the University of Minnesota; and Annie and Bob Graham. We thank Dr. D. Smith of the Yellowstone Wolf Project for providing stipend funds for SMB-M. CRJ was supported by a National Institutes of Health-National Institute on Drug Abuse training grant (T32-DA-07239). Comments from Drs. M. Carstensen Powell, G. DelGiudice, S. Ditchkoff, M. Nelson, and 1 anonymous reviewer greatly improved earlier drafts. Dr. S. Weisberg from the University of Minnesota Statistical Department provided statistical advice.

\section{Literature Cited}

Adams, L. G., F. J. Singer, And B. W. Dale. 1995. Caribou calf mortality in Denali National Park, Alaska. Journal of Wildlife Management 59:584-594.

Altmann, M. 1952. Social behavior of elk, Cervus canadensis nelsoni, in the Jackson Hole area of Wyoming. Behaviour 4: 116-143.

Animal Care and Use Committee. 1998. Guidelines for the capture, handling, and care of mammals as approved by the American Society of Mammalogists. Journal of Mammalogy 79:1416-1431.

Barber, S., L. D. Mech, AND P. J. White. 2005. Yellowstone elk calf mortality following wolf restoration: bears remain top summer predators. Yellowstone Science 13:37-44.

Beutler, B., And A. Cerami. 1989. The biology of cachectin/TNFalpha: primary mediator of the host response. Annual Review of Immunology 7:625-655.

Call, D., M. Jacoby, K. Rudolph, G. Bolgos, C. Robbins, And D. REMICK. 2000. Detecting wildlife orthologues for tumor necrosis factor (TNF) and interleukin-6 (IL-6). Northwest Science 74: $340-345$.

CAnnon, J. 1995. Cytokines in aging and muscle homeostasis. Journals of Gerontology. Series A, Biological Sciences and Medical Sciences 50:120-123.
Carstensen Powell, M. 2004. Winter severity, deer nutrition, and fawning characteristics. Ph.D. dissertation, University of Minnesota, St. Paul.

Carstensen Powell, M., G. D. Delgiudice, and B. A. Sampson. 2005. Low risk of marking-induced abandonment in free-ranging white-tailed deer neonates. Wildlife Society Bulletin 33:643-655.

Cook, R. C., J. G. CoOK, AND L. D. Мech. 2004. Nutritional condition of northern Yellowstone elk. Journal of Mammalogy 85:714-722.

CoOK, R. D., AND S. Weisberg. 1999. Applied regression including computing and graphics. John Wiley \& Sons, Inc., New York.

Crabtree, R. L., and J. W. Sheldon. 1999. Coyotes and canid coexistence. Pp. 127-163 in Carnivores in ecosystems: the Yellowstone experience (T. W. Clark, A. P. Curlee, S. C. Minta, and P. M. Kareiva, eds.). Yale University Press, New Haven, Connecticut.

DAMAs, P., ET AL. 1992. Cytokine serum level during severe sepsis in humans: IL-6 as a marker of severity. Annals of Surgery 215: 356-362.

DelGiudice, G. D., L. D. Mech, K. E. Kunkel, E. M. Gese, and U. S. SEAL. 1992. Seasonal patterns of weight, hematology, and serum characteristics of free-ranging female white-tailed deer in Minnesota. Canadian Journal of Zoology 70:974-983.

Despain, D. G. 1990. Yellowstone vegetation. Robert Rinehart, Boulder, Colorado.

Ditchkoff, S. S., M. G. SAms, R. L. Lochmiller, And D. M. Leslie, JR. 2001. Utility of necrosis factor- $\alpha$ and interleukin- 6 as predictors of neonatal mortality in white-tailed deer. Journal of Mammalogy 82:239-245.

Duffy, L. K., R. T. Bowyer, J. W. Testa, and J. B. Faro. 1994a. Chronic effects of the Exxon Valdez oil spill on blood and enzyme chemistry of river otters. Environmental Toxicology and Chemistry 13:643-647.

Duffy, L. K., R. T. Bowyer, J. W. Testa, and J. B. Faro. 1994b. Evidence for recovery of body mass and haptoglobin values of river otters following Exxon Valdez oil spill. Journal of Wildlife Diseases 30:421-425.

Farnes, P. E., C. Heydon, and K. Hansen. 1999. Snowpack distribution across Yellowstone National Park. Department of Earth Sciences, Montana State University, Bozeman, Montana, Final report CA 1268-1-9017:1-58.

FERRUCCI, L., ET AL. 1999. Serum IL-6 level and the development of disability in older persons. Journal of the American Geriatric Society 47:639-646.

Franzmann, A. W., And R. E. LeResche. 1978. Alaskan moose blood studies with emphasis on condition evaluation. Journal of Wildlife Management 42:334-351.

Garner, G. W., K. R. Whitten, And F. J. Mauer. 1985. Methodology for studying neonatal mortality of caribou in remote areas. Pp. 139152 in Proceedings of Second North American Caribou Workshop (T. C. Meredith and A. M. Martell, eds.). McGill University, Montreal, Quebec, Canada.

GeIst, V. 2002. Adaptive behavioral strategies. Pp. 389-433 in North American elk: ecology and management (D. E. Toweill and J. W. Thomas, eds.). Smithsonian Institution Press, Washington, D.C.

HamLIN, K. L., AND M. S. Ross. 2002. Effects of hunting regulation changes on elk and hunters in the Gravelly-Snowcrest Mountains, Montana. Montana Fish, Wildlife and Parks, Wildlife Division, Helena, Montana, Federal Aid Project W-120-R, April 2002:1-237. Haroldson, M. A., And K. Frey. 2005. Grizzly bear mortalities. Pp. 24-29 in Yellowstone grizzly bear investigations: annual report of the Interagency Grizzly Bear Study Team, 2004 (C. C. Schwartz 
and M. A. Haroldson, eds.). United States Geological Survey, Bozeman, Montana.

HARRIS, T., ET AL. 1999. Associations of elevated interleukin-6 and C-reactive protein levels with mortality in elderly. American Journal of Medicine 106:506-512.

Haugen, A. O., And W. SPeaKe. 1958. Determining the age of young white-tailed deer. Journal of Wildlife Management 22:319-321.

Houston, D.B. 1982. The northern Yellowstone elk: ecology and management. Macmillian Publishing Company, New York.

Johnson, D. E. 1951. Biology of the elk calf, Cervus canadensis nelsoni. Journal of Wildlife Management 15:396-410.

Kie, J. G., M. White, And D. L. Drawe. 1983. Condition parameters of white-tailed deer in Texas. Journal of Wildlife Management 47:583-594.

Kirkpatrick, R. L., D. E. Buckland, W. A. Abler, P. F. Scanlon, J. B. Whelan, and H. E. Burkhart. 1975. Energy and protein influences on blood urea nitrogen of white-tailed deer fawns. Journal of Wildlife Management 39:692-698.

KreBs, C. J. 1999. Ecological methodology. 2nd ed. Addison Wesley Longman, Inc., Menlo Park, California.

KunKel, K. E., AND L. D. Mech. 1994. Wolf and bear predation on white-tailed deer fawns in northeastern Minnesota. Canadian Journal of Zoology 72:1557-1565.

Larsen, D. G., D. A. Gauthier, and R. L. Markel. 1989. Causes and rates of mortality of moose in southwestern Yukon. Journal of Wildlife Management 53:548-557.

LeResche, R. E., U. S. Seal, P. D. Karns, and A. W. Franzmann. 1974. A review of blood chemistry of moose and other cervidae, with emphasis on nutritional assessment. Le Naturaliste Canadien 101:263-290.

Lochmiller, R., R. Michelle, and S. McMurray. 1994. Temporal variation in humoral and cell-mediated immune response in a Sigmondon hispidus population. Ecology 75:236-245.

McCullagh, P., and J. A. Nelder. 1989. Generalized linear models. 2nd ed. Chapman \& Hall, New York.

Moore, T. D., L. E. Spence, And C. G. Dugnolle. 1974. Identification of dorsal guard hairs of some mammals of Wyoming. Wyoming Game Fish Department Bulletin 14:1-177.

O'GARA, B. W. 1978. Differential characteristics of predator kills. Proceedings of Antelope States Workshop 8:380-393.

Pradhan, A., J. Manson, N. Rifai, J. Buring, and P. Ridker. 2001. C-reactive protein, IL 6, and risk of developing type 2 diabetes mellitus. Journal of the American Medical Association 286:327-334.

Remick, D., AND J. Friedland (EDS.). 1997. Cytokines in health and disease 2nd ed. Dekker, New York.

Ruth, T. K. 2004. "Ghost of the Rockies"- the Yellowstone cougar project. Yellowstone Science 12:13-24.
SAMS, M. G. 1994. The relationship between maternal condition and fawn survival in an overpopulated white-tailed deer herd in northeastern Oklahoma. M.S. thesis, Oklahoma State University, Stillwater.

Sams, M. G., R. L. Lochmiller, C. W. Qualls, JR., D. M. Leslie, JR., AND M. E. PAYTOn. 1996. Physiological correlates of neonatal mortality in an overpopulated herd of white-tailed deer. Journal of Mammalogy 77:179-190.

Seal, U. S., and R. L. Hoskinson. 1978. Metabolic indicators of habitat condition and capture stress in pronghorns. Journal of Wildlife Management 42:755-763.

Seal, U. S., M. E. Nelson, L. D. Mech, and R. L. Hoskinson. 1978a. Metabolic indicators of habitat differences in four Minnesota deer populations. Journal of Wildlife Management 42:746-754.

Seal, U. S., L. J. Verme, And J. J. Ozoga. 1978b. Dietary protein and energy effects on deer fawn metabolic patterns. Journal of Wildlife Management 42:776-790.

Singer, F. J., A. Harting, K. K. Symonds, and M. B. Coughenour 1997. Density dependence, compensation, and environmental effects on elk calf mortality in Yellowstone National Park. Journal of Wildlife Management 61:12-25.

Smith, B. L., R. L. Robbins, and S. H. Anderson. 1997. Early development of supplementally fed, free-ranging elk. Journal of Wildlife Management 61:27-39.

Sмiтh, D. W. 2005. Ten years of Yellowstone wolves. Yellowstone Science 13:7-33.

Spaulding, C. C., R. L. Walford, AND R. B. Effros. 1997. Calorie restriction inhibits the age-related dysregulation of the cytokines TNF- $\alpha$ and IL-6 in C3B10RF1 mice. Mechanisms of Ageing and Development 93:87-94.

TIZARD, I. 1992. Veterinary immunology: an introduction. W.B. Saunders Company, Philadelphia, Pennsylvania.

WADE, D. A., AND J. E. Bowns. 1985. Procedures for evaluating predation on livestock and wildlife. Texas Agricultural Extension Service, Texas A\&M University, San Angelo, Texas, Bulletin B-1429:1-42.

Weber, B. J., M. L. Wolfe, G. C. White, and M. M. Rowland. 1984. Physiologic response of elk to differences in winter range quality. Journal of Wildlife Management 48:248-253.

White, P. J., AND R. A. GARRott. 2005. Yellowstone's ungulates after wolves-expectations, realizations, and predictions. Biological Conservation 125:141-152.

Submitted 19 June 2006. Accepted 7 August 2006.

Associate Editor was Craig L. Frank. 